\title{
Subribosomal particle analysis reveals the stages of bacterial ribosome assembly at which rRNA nucleotides are modified
}

\author{
TRIINU SIIBAK ${ }^{\mathbf{1}, \mathbf{2}}$ and JAANUS REMME ${ }^{\mathbf{1}}$ \\ ${ }^{1}$ Institute of Molecular and Cell Biology, University of Tartu, Tartu 51010, Estonia \\ ${ }^{2}$ Insitute of Technology, University of Tartu, Tartu 51010, Estonia
}

\begin{abstract}
Modified nucleosides of ribosomal RNA are synthesized during ribosome assembly. In bacteria, each modification is made by a specialized enzyme. In vitro studies have shown that some enzymes need the presence of ribosomal proteins while other enzymes can modify only protein-free rRNA. We have analyzed the addition of modified nucleosides to rRNA during ribosome assembly. Accumulation of incompletely assembled ribosomal particles (25S, 35S, and 45S) was induced by chloramphenicol or erythromycin in an exponentially growing Escherichia coli culture. Incompletely assembled ribosomal particles were isolated from drug-treated and free $30 S$ and $50 S$ subunits and mature $70 S$ ribosomes from untreated cells. Nucleosides of 165 and $23 S$ rRNA were prepared and analyzed by reverse-phase, high-performance liquid chromatography (HPLC). Pseudouridines were identified by the chemical modification/primer extension method. Based on the results, the rRNA modifications were divided into three major groups: early, intermediate, and late assembly specific modifications. Seven out of 11 modified nucleosides of $16 S$ rRNA were late assembly specific. In contrast, 16 out of 25 modified nucleosides of $23 S$ rRNA were made during early steps of ribosome assembly. Free subunits of exponentially growing bacteria contain undermodified rRNA, indicating that a specific set of modifications is synthesized during very late steps of ribosome subunit assembly.
\end{abstract}

Keywords: modified nucleosides; ribosome assembly; chloramphenicol; erythromycin; rRNA

\section{INTRODUCTION}

Ribosome assembly involves several coordinated reactions. Folding, nucloelytic processing, and post-transcriptional modification of rRNA occur concomitantly with the r-protein association with the rRNA. Modification of rRNA is thereby an integral part of ribosome assembly process. Escherichia coli $16 \mathrm{~S}$ rRNA contains 11 and 23S rRNA contains 25 modified nucleosides (Ofengand and Del Campo 2004). Eleven pseudouridines and 21 base methylations make up the bulk of modified nucleosides in E. coli rRNA. Each rRNA modification is made by a specific enzyme. In E. coli there are 32 rRNA modification enzymes in total, 25 of them are methyltransferases and seven pseudouridine synthases. All the pseudouridine synthases and most of the rRNA methyltransferases have been identified (Ofengand and Del Campo 2004; Purta et al.

Reprint requests to: Jaanus Remme, Institute of Molecular and Cell Biology, University of Tartu, Riia 23, Tartu 51010, Estonia; e-mail: jremme@ebc.ee; fax: +372-7420286.

Article published online ahead of print. Article and publication date are at http://www.rnajournal.org/cgi/doi/10.1261/rna.2160010.
2009). The substrate specificity of the rRNA modification enzymes has been studied mostly by cell-free experiments using purified enzymes. The specificity of specific rRNA modification has been shown to depend on the presence of r-proteins (Ofengand and Del Campo 2004). Substrate specificities of rRNA modification enzymes with respect to ribosome assembly are summarized in Table 1.

Ribosome assembly in bacteria is fast and efficient. In wildtype bacteria ribosome subunits are formed within 2-3 min at $37^{\circ} \mathrm{C}$ (Lindahl 1975). Chloramphenicol is known to inhibit assembly of both ribosome subunits (Dagley and Sykes 1959; Kurland et al. 1962). More recently many other antibiotics were shown to cause ribosome assembly defects (for review, see Champney 2006). Chloramphenicol and erythromycin were shown to inhibit assembly of both ribosome subunits due to the unbalanced synthesis of ribosomal components (Dodd et al. 1991; Siibak et al. 2009). In the presence of these antibiotics incompletely assembled ribosome subunits accumulate in the cells (Siibak et al. 2009). Here we report the results of quantitative analysis of modified nucleosides of $16 \mathrm{~S}$ and $23 \mathrm{~S}$ rRNA in the antibiotic-induced 
TABLE 1. Modified nucleosides in Escherichia coli rRNAs and the specificities of the corresponding enzymes

\begin{tabular}{|c|c|c|c|c|}
\hline Modification & Enzyme & $\begin{array}{c}\text { Stage } \\
\text { of assembly }\end{array}$ & Comment & Reference \\
\hline \multicolumn{5}{|l|}{ 16S rRNA } \\
\hline$\Psi 516$ & RsuA & Intermediate & Some proteins & Wrzesinski et al. (1995) \\
\hline$m^{7} \mathrm{G} 527$ & RsmG & Late & $30 S$ & Okamoto et al. (2007) \\
\hline $\mathrm{m}^{2} \mathrm{G} 966$ & RsmD & Late & Requires S7 and S19 & Weitzmann et al. (1991) \\
\hline $\mathrm{m}^{5} \mathrm{C} 967$ & RsmB & Late & Blocked by S7 and S19 & Weitzmann et al. (1991) \\
\hline $\mathrm{m}^{2} \mathrm{G} 1207$ & RsmC & Late & $30 S$ & Tscherne et al. (1999) \\
\hline $\mathrm{m}^{4} \mathrm{C} 1402$ & $\mathrm{RsmH}$ & Late & $30 S$ & Kimura and Suzuki (2010) \\
\hline $\mathrm{Cm} 1402$ & Rsml & Late & $30 \mathrm{~S}$ & Kimura and Suzuki (2010) \\
\hline $\mathrm{m}^{5} \mathrm{C} 1407$ & RsmF & Late & $30 \mathrm{~S}$ & Andersen and Douthwaite (2006) \\
\hline $\mathrm{m}^{3} \mathrm{U} 1498$ & RsmE & Late & $30 S$ & Basturea and Deutscher (2007) \\
\hline $\mathrm{m}_{2}^{6} \mathrm{~A} 1518$ & RsmA & Late & $30 \mathrm{~S}$ & Poldermans et al. (1979) \\
\hline $\mathrm{m}_{2}^{6} \mathrm{~A} 1519$ & RsmA & Late & $30 \mathrm{~S}$ & Poldermans et al. (1979) \\
\hline \multicolumn{5}{|l|}{$23 \mathrm{~S}$ rRNA } \\
\hline$m^{1} G 745$ & $\mathrm{R} \operatorname{lm} A$ & Early & 23S rRNA & Hansen et al. (2001) \\
\hline$m^{6} A 1618$ & $\mathrm{RImF}$ & Intermediate & 3.5M LiCl particle & Sergiev et al. (2008) \\
\hline $\mathrm{m}^{2} \mathrm{G} 1835$ & RlmG & Early & $23 \mathrm{~S}$ rRNA & Sergiev et al. (2006) \\
\hline$\Psi 1911$ & RluD & Late & $50 \mathrm{~S}$ & Leppik et al. (2007) \\
\hline$\psi 1915$ & RluD & Late & $50 S$ & Leppik et al. (2007) \\
\hline$\Psi 1917$ & RluD & Late & $50 S$ & Leppik et al. (2007) \\
\hline $\mathrm{m}^{3} \psi 1915$ & $\mathrm{RImH}$ & Late & $70 S$ & Ero et al. (2008) \\
\hline $\mathrm{m}^{5} \mathrm{C} 1962$ & Rlml & Early & $23 \mathrm{~S}$ rRNA & Purta et al. (2008) \\
\hline $\mathrm{m}^{2} \mathrm{G} 2445$ & RImL & Early & $23 \mathrm{~S}$ rRNA & Lesnyak et al. (2006) \\
\hline Cm2498 & $\operatorname{RImM}$ & Early & 23S rRNA & Purta et al. (2009) \\
\hline Um2552 & RImE & Late & $50 S, 70 S$ & Caldas et al. (2000); Bügl et al. (2000) \\
\hline
\end{tabular}

ribosomal particles stalled at different assembly stages using reverse-phase, high-performance liquid chromatography (HPLC). Pseudouridines at specific positions of $23 \mathrm{~S}$ rRNA were identified by the chemical modification/primer extension method. The results allowed dividing the rRNA modification enzymes with respect to ribosome assembly in vivo into three classes: early, intermediate, and late assembly specific enzymes.

\section{RESULTS}

\section{Isolation of "chloramphenicol and erythromycin particles" $^{\prime \prime}$}

In order to analyze the temporal relationship between rRNA modification and ribosome subunit assembly, rRNA from incompletely assembled ribosomal subunits was analyzed with respect to the modified nucleoside composition. Accumulation of assembly defective ribosomal subunits was induced by chloramphenicol or erythromycin in an exponentially growing E. coli culture.

Ribosomal particles were separated by sucrose gradient centrifugation (Fig. 1). Addition of chloramphenicol or erythromycin to the growth medium leads to the appearance of three unusual ribosomal particles termed the 25S, 35S, and $45 \mathrm{~S}$ particles. $35 \mathrm{~S}$ and $45 \mathrm{~S}$ particles are related to the $50 \mathrm{~S}$ subunit and $25 \mathrm{~S}$ particles are related to the $30 \mathrm{~S}$ subunit (Fig. 1 ), in agreement with the earlier observations (Usary and
Champney 2001; Siibak et al. 2009). In the absence of drugs the ribosome small subunit has one precursor $(21 \mathrm{~S})$ and the large subunit has two precursors ( $34 \mathrm{~S}$ and $43 \mathrm{~S}$ ) (Nierhaus 1991). It is possible that the $25 \mathrm{~S}, 35 \mathrm{~S}$, and $45 \mathrm{~S}$ assembly defective particles formed upon addition of antibiotics are related to the precursor particles found in vivo. The precursor rRNA from the "chloramphenicol particles" is converted into normal $30 \mathrm{~S}$ and $50 \mathrm{~S}$ ribosomes without prior degradation upon removal of the drug (Nomura and Hosokawa 1965; Adesnik and Levinthal 1969). Therefore, the subribosomal particles formed in the presence of chloramphenicol are ribosome subunit assembly intermediate particles.

No free $30 \mathrm{~S}$ or $50 \mathrm{~S}$ subunits were found in the presence of chloramphenicol or erythromycin (Fig. 1), suggesting that the limiting step of ribosome subunit assembly in the presence of protein synthesis inhibitors is ribosomal protein production. Sucrose gradient fractions containing particles of interest were combined, concentrated by ultrafiltration, and repurified by a second sucrose gradient. It is worth mentioning that sedimenting the subribosomal particles leads to hardly soluble pellet. Therefore, ultrafiltration is the preferable method for concentrating the subribosomal particles. The second sucrose gradient centrifugation yielded homogenous particles. Isolation of chloramphenicol induced particles is shown in Figure 1D-F. rRNA was obtained by phenol extraction. The $25 \mathrm{~S}$ and $45 \mathrm{~S}$ particles contained only $16 \mathrm{~S}$ and $23 \mathrm{~S}$ rRNA, respectively (data not shown). The $35 \mathrm{~S}$ particles contained a mixture of $16 \mathrm{~S}$ and $23 \mathrm{~S}$ rRNAs. The 


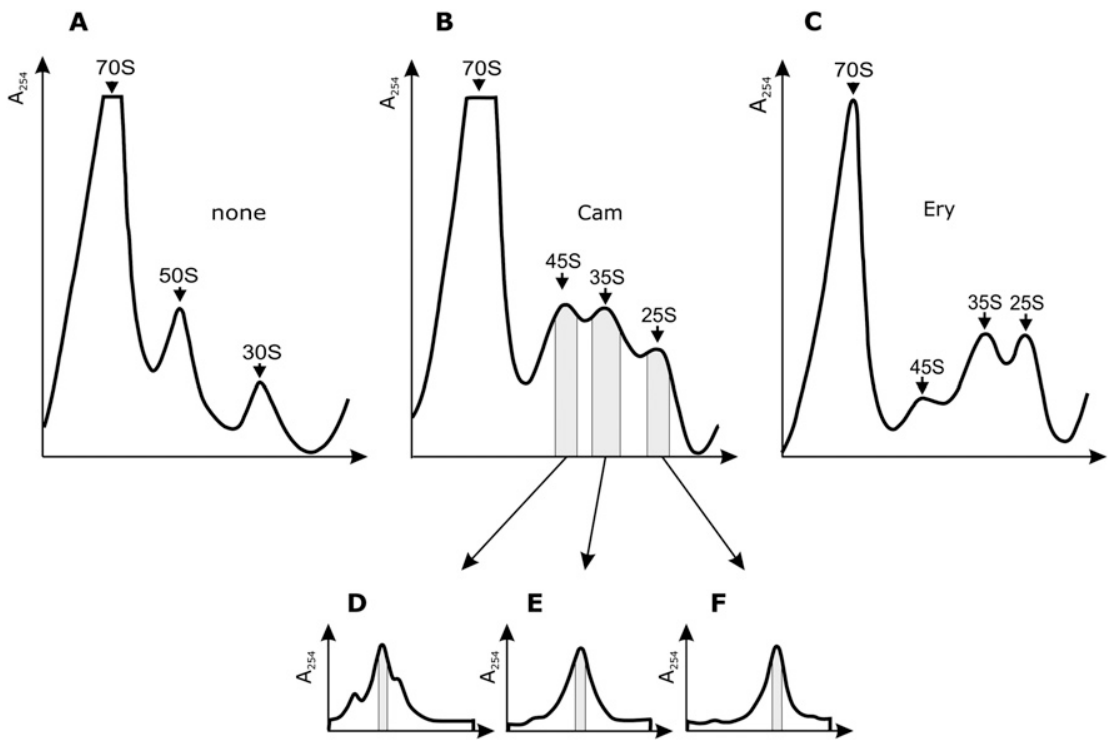

FIGURE 1. Isolation of ribosomal particles from E. coli grown in the presence of chloramphenicol or erythromycin or in the absence of a drug. Exponentially growing bacterial cells without the drug $(A)$, or treated with chloramphenicol $(B)$, or erythromycin $(C)$ were lysed and centrifuged in 10\%-25\% sucrose. $45 \mathrm{~S}$, 35S, and $25 \mathrm{~S}$ fractions of chloramphenicol and erythromycin treated cells were combined (only chloramphenicol particles are indicated by gray zones in $B$ ). Ribosomal particles were purified by a second sucrose gradient centrifugation $(D-F)$. Indicated fractions were collected.

two rRNA species were separated from each other by sucrose gradient centrifugation (Fig. 2B).

Free $30 \mathrm{~S}$ and $50 \mathrm{~S}$ subunits were isolated from exponentially growing $E$. coli cells (at $25^{\circ} \mathrm{C}$ ) by two consecutive sucrose gradient centrifugation methods as described above for subribosomal particles. It must be noted that the free ribosome subunits in these conditions are mostly assembly intermediate particles $(\sim 80 \%)$ with low functional activity (Peil et al. 2008). The limiting step of large ribosome subunit assembly is the final maturation at the level of the $50 \mathrm{~S}$ particles (Lindahl 1975; Peil et al. 2008). Therefore, it was interesting to analyze the modified nucleoside composition of rRNA of the free $30 \mathrm{~S}$ and 50S subunits. Ribosomal RNA was deproteinized by phenol extraction. Mature $16 \mathrm{~S}$ and $23 \mathrm{~S}$ rRNA species were isolated from $70 \mathrm{~S}$ ribosomes by phenol extraction followed by sucrose gradient centrifugation (Fig. 2A).

\section{Modification of $16 S$ rRNA during $30 S$ subunit assembly}

Analytical reverse-phase HPLC (RP-HPLC) allows identifying all nucleotides of $E$. coli $16 \mathrm{~S}$ rRNA and nearly all nucleosides of E. coli $23 S$ rRNA (Gehrke and Kuo 1989). Moreover, this method enables quantitative estimation of nucleosides. Therefore we have used RP-HPLC for determination of modified nucleosides in rRNA species. Nucleosides were prepared by treatment of the rRNA with nuclease P1 and bacterial alkaline phosphatase. Chromatographic peak assignments to the specific modified nucleosides were derived from relative retention times according to Gehrke and Kuo (1989). The $\mathrm{A}_{260} / \mathrm{A}_{280}$ ratio was used to confirm the peak identities. The RPHPLC peak surface area corresponding to each nucleoside was calculated and compared with the respective nucleoside peak area of mature 16S rRNA of 70S ribosomes (Fig. 3; Table 2). Mature 16S rRNA isolated from $70 \mathrm{~S}$ ribosomes has been shown to contain stochiometric amounts of modified nucleosides within 10\% error limit (Gehrke and Kuo 1989). At least three independent particle preparations were analyzed with respect to modified nucleoside content.

The $25 \mathrm{~S}$ particles formed in the presence of Cam or Ery contain only $16 \mathrm{~S}$ rRNA that is incompletely processed (Siibak et al. 2009). 16S rRNA of both Cam and Ery 25S particles clearly contain several modified nucleosides, albeit at a lower level compared with the mature 30 S particles (Fig. 3; Table 2). Both Cam and Ery $25 \mathrm{~S}$ particles have similar nucleoside composition (Fig. 3; Table 2). Pseudouridine, $\mathrm{m}^{5} \mathrm{C}$, and $\mathrm{m}^{4} \mathrm{Cm}$ are present in $25 \mathrm{~S}$ particles between $40 \%$ and $60 \%$ compared with the mature $16 \mathrm{~S}$ rRNA. $\mathrm{m}^{7} \mathrm{G}$ and $\mathrm{m}^{2} \mathrm{G}$ are found in $25 \mathrm{~S}$ particles in $<25 \% . \mathrm{m}^{5} \mathrm{U}$ and $\mathrm{m}_{2}^{6} \mathrm{~A}$ are found in $25 \mathrm{~S}$ particles only in trace amounts (Table 2). The results were well reproducible, except in $\mathrm{m}^{4} \mathrm{Cm}$, which exhibited significant variation in different preparations. Thus, $16 \mathrm{~S}$ rRNA is modified only at low levels during early events of $30 \mathrm{~S}$ subunit assembly.

In the bacteria grown at $25^{\circ} \mathrm{C}, 70 \%-80 \%$ of the free $30 \mathrm{~S}$ particles contain the $16 \mathrm{~S}$ rRNA precursor with 115 extra nucleotides at the $5^{\prime}$ end (Siibak et al. 2009), indicating that the majority of these particles are incompletely assembled precursors of the ribosome small subunit. The modification level of 16S rRNA is still incomplete compared with the mature rRNA. Free 30S subunits contain nearly $90 \%$ of pseudouridine and $80 \%$ of $\mathrm{m}^{7} \mathrm{G}$ (Table 1 ). Thus the majority of these modifications are introduced into $16 \mathrm{~S}$ rRNA during intermediate stages of small subunit assembly. Formation of $\mathrm{m}^{4} \mathrm{Cm}$ seems also to occur during intermediate assembly stages, although only $70 \%$ was found in the free $30 \mathrm{~S}$ fraction and a large variability of results was observed (Table 2 ). $\mathrm{m}^{5} \mathrm{U}$ and $\mathrm{m}_{2}^{6} \mathrm{~A}$ are present in the free $30 \mathrm{~S}$ particles at $\sim 20 \%$ level (Table 2), which is about the same fraction as the mature $5^{\prime}$ end of $16 \mathrm{~S}$ was found. Therefore, $\mathrm{m}^{5} \mathrm{U}$ and $\mathrm{m}_{2}^{6} \mathrm{~A}$ can be classified as late assembly specific modifications. $\mathrm{m}^{2} \mathrm{G}$ (positions G966, G1207, and G1516) and $\mathrm{m}^{5} \mathrm{C}$ (C967 and C1407) are present at multiple positions of $E$. coli $16 \mathrm{~S}$ and therefore cannot be clearly assigned to a specific ribosome assembly stage. 

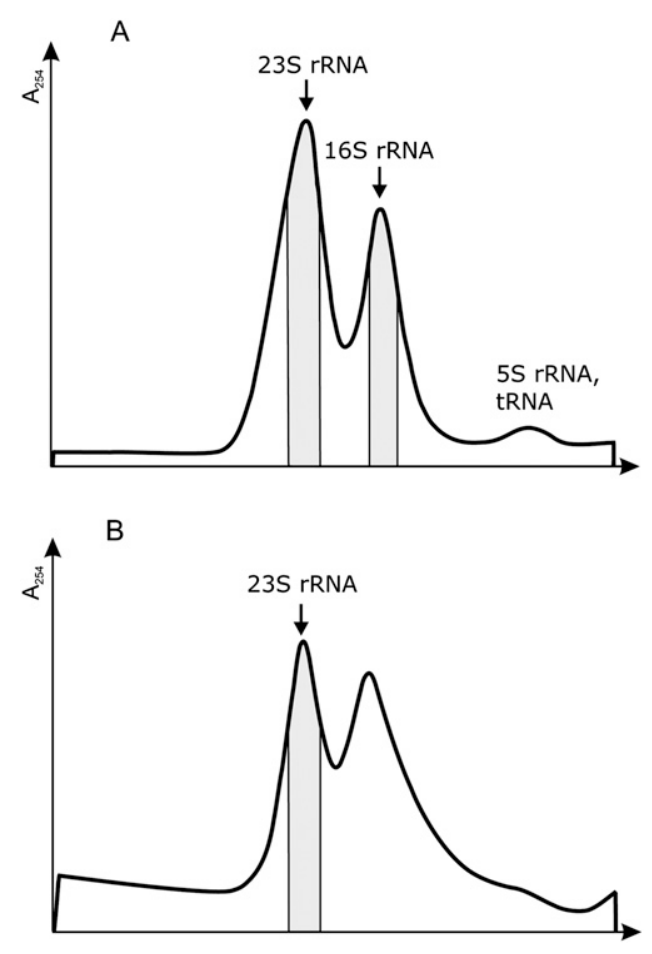

FIGURE 2. Purification of ribosomal RNA by sucrose gradient centrifugation. Ribosomal RNA from $70 \mathrm{~S}$ ribosomes $(A)$ and $35 \mathrm{~S}$ particles $(B)$ was deproteinized by phenol extraction and centrifuged in $5 \%-20 \%$ (w/w) sucrose gradient (buffer $20 \mathrm{mM} \mathrm{Na}$-acetate, $100 \mathrm{mM}$ $\mathrm{NaCl}, 1 \mathrm{mM}$ EDTA) at 25,700 rpm in an SW28 rotor (Beckman) for $16 \mathrm{~h}$. $16 \mathrm{~S}$ and $23 \mathrm{~S}$ rRNA were collected as indicated by the gray zones.

\section{Modification of 23S rRNA}

23S rRNA was isolated from the Ery- and Cam-induced 35S and $45 \mathrm{~S}$ assembly intermediate particles, from the free $50 \mathrm{~S}$ subunits, and from the mature 705 ribosomes of untreated cells (Figs. 1, 2). It must be noted that the free $50 \mathrm{~S}$ subunits are in the majority $(80 \%)$ assembly intermediate particles (Peil et al. 2008; Al Refaii and Alix 2009), The RP-HPLC method used allows identifying all $23 \mathrm{~S}$ rRNA modifications except three. $\mathrm{m}^{3} \Psi$ (present at position 1915 of $23 \mathrm{~S} \mathrm{rRNA}$ ) and $\mathrm{m}^{5} \mathrm{C}$ (1962) have identical retention times (Kowalak et al. 1996). However, taking into account that the formation of $\mathrm{m}^{3} \Psi$ occurs on the level of $70 \mathrm{~S}$ ribosomes (Ero et al. 2008), the RP-HPLC peak at 11.4 min of $35 \mathrm{~S}$ and $45 \mathrm{~S}$ particles probably contain only $\mathrm{m}^{5} \mathrm{C}$. The third nucleoside, which was not analyzed, is an incomplete modification at C2501 whose retention time is not known.

The $35 \mathrm{~S}$ particles formed in the presence of Ery or Cam exhibited similar nucleoside composition. The particles an unknown compound. contain several modified nucleosides in nearly stochiometric amounts. $\mathrm{m}^{1} \mathrm{G}, \mathrm{m}^{6} \mathrm{~A}, \mathrm{~m}^{2} \mathrm{G}, \mathrm{m}^{7} \mathrm{G}$, and $\mathrm{m}^{2} \mathrm{~A}$ are already present in the first assembly intermediate particles by $80 \%$ or more (Table 3). This suggests that these modifications are formed during an early step of large subunit assembly. Pseudouridines, $\mathrm{m}^{5} \mathrm{U}, \mathrm{m}^{5} \mathrm{C}, \mathrm{Gm}$, and $\mathrm{Cm}$ are present in the $35 \mathrm{~S}$ particles by $40 \%-70 \%$ (Table 3 ). Um was not found in the $23 \mathrm{~S}$ rRNA isolated from $35 \mathrm{~S}$ particles (Fig. 4). Thus, $\mathrm{m}^{1} \mathrm{G}$, $m^{6} \mathrm{~A}, \mathrm{~m}^{2} \mathrm{G}, \mathrm{m}^{7} \mathrm{G}, \mathrm{m}^{5} \mathrm{C}$, and $\mathrm{m}^{2} \mathrm{~A}$ are formed during the early steps of $50 \mathrm{~S}$ subunit assembly.

A significant increase of the $\mathrm{m}^{5} \mathrm{U}, \mathrm{Gm}, \mathrm{Cm}$, and Um levels was observed in the $45 \mathrm{~S}$ particles compared with the $35 \mathrm{~S}$ particles (Table 3 ). However, the Um level is still only $35 \%$ of mature 23S rRNA (Table 3). We conclude that synthesis of $\mathrm{m}^{5} \mathrm{U}, \mathrm{Gm}$, and $\mathrm{Cm}$ occurs during the intermediate steps of large ribosome subunit assembly.

Free 50S particles isolated from exponentially growing cultures represent $\sim 80 \%$ large subunit assembly intermediate particles according to the processing status of the $23 \mathrm{~S}$ rRNA $5^{\prime}$ end and the translational activity (Peil et al. 2008). Most of the modified nucleosides are present in the free 50S particles by $90 \%-100 \%$ in comparison with the mature $23 \mathrm{~S}$ rRNA (Table 3). However, Um is present in the free $50 \mathrm{~S}$ particles by $63 \%$ of the mature $23 \mathrm{~S}$ rRNA level (Table 3 ). This result is in agreement with the free $50 \mathrm{~S}$ particles being incompletely assembled and shows that Um together with $\mathrm{m}^{3} \Psi$ (see below) are added during the late steps of ribosome large subunit assembly.

\section{Pseudouridines in 235 rRNA}

Pseudouridylation is the most abundant modification in stable RNAs. There are 10 pseudouridines in E. coli $23 \mathrm{~S}$ rRNA, one of them is methylated $\left(\mathrm{m}^{3} \Psi 1915\right) . \Psi$ residues

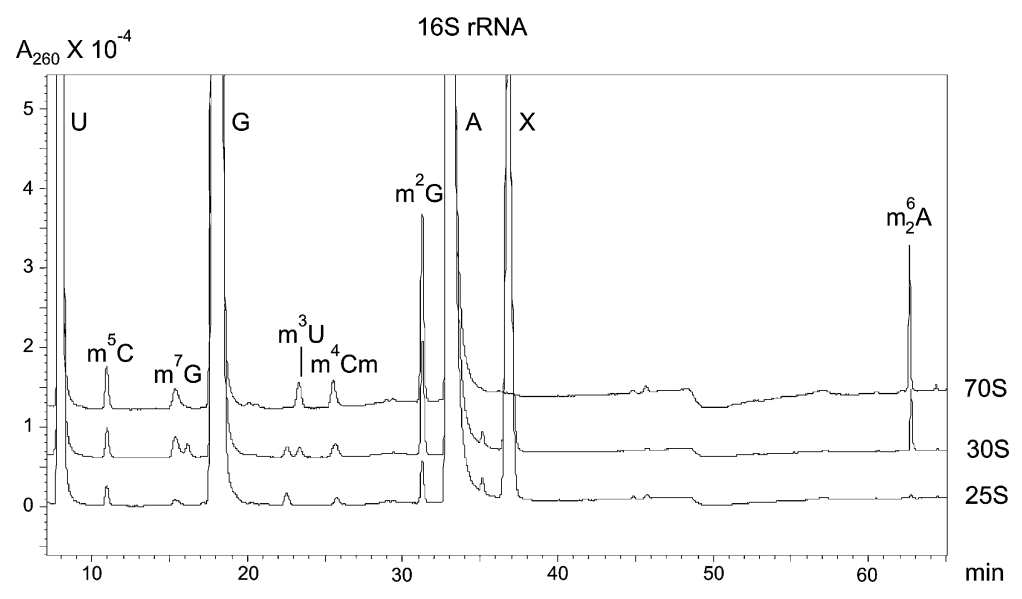

FIGURE 3. HPLC analysis of $16 \mathrm{~S}$ rRNA. $16 \mathrm{~S}$ rRNA was prepared from mature $70 \mathrm{~S}$ ribosomes, free $30 \mathrm{~S}$ subunits, and Cam $25 \mathrm{~S}$ particles. Nucleoside composition was determined by RP-HPLC on a Supelcosil LC-18-S. Peaks corresponding to three standard nucleosides $\left(\mathrm{U}, \mathrm{G}\right.$, and $\mathrm{A}$ ) and $\mathrm{m}^{5} \mathrm{C}, \mathrm{m}^{7} \mathrm{G}, \mathrm{m}^{3} \mathrm{U}, \mathrm{m}^{4} \mathrm{Cm}, \mathrm{m}^{2} \mathrm{G}$, and $\mathrm{m}_{2}{ }_{2} \mathrm{~A}$ are indicated. $\mathrm{X}$ corresponds to 
TABLE 2. Nucleoside composition of $16 \mathrm{~S}$ rRNA of the different stages of small ribosome subunit assembly

\begin{tabular}{lccc}
\hline Nucleoside & Free 30S & Ery 25S & Cam 25S \\
\hline$\psi(516)$ & $87 \pm 11$ & $56 \pm 5$ & $61 \pm 17$ \\
$\mathrm{~m}^{7} \mathrm{G}(527)$ & $83 \pm 16$ & $15 \pm 5$ & $22 \pm 8$ \\
$\mathrm{~m}^{2} \mathrm{G}(966,1207,1516)$ & $45 \pm 15$ & $21 \pm 2$ & $24 \pm 3$ \\
$\mathrm{~m}^{5} \mathrm{C}(967,1407)$ & $58 \pm 10$ & $48 \pm 1$ & $48 \pm 1$ \\
$\mathrm{~m}^{4} \mathrm{Cm}(1402)$ & $70 \pm 15$ & $55 \pm 27$ & $54 \pm 29$ \\
$\mathrm{~m}^{3} \mathrm{U}(1498)$ & $20 \pm 13$ & $4 \pm 2$ & $3 \pm 3$ \\
$\mathrm{~m}^{6} \mathrm{~A}(1518,1519)$ & $23 \pm 18$ & $3 \pm 2$ & $3 \pm 1$ \\
\hline
\end{tabular}

Ribosomal particles were isolated from E. coli grown in the presence of chloramphenicol or erythromycin or in the absence of drugs. Nucleosides of the 16S rRNA were separated and quantified by reverse-phase HPLC. Amount of nucleosides is expressed as percentage of mature $70 \mathrm{~S}$ ribosomes as average of three independent experiments.

were quantitated by RP HPLC. According to the HPLC analysis, 35S particles contain $65 \%-70 \%$, $45 \mathrm{~S}$ particles contain $80 \%$, and free 50 S subunits contain $90 \%$ of pseudouridines compared with the $23 \mathrm{~S}$ rRNA of $70 \mathrm{~S}$ ribosomes (Table 2). It must be taken into account that the methylated pseudouridine $\left(\mathrm{m}^{3} \Psi\right)$ co-elutes with $\mathrm{m}^{5} \mathrm{C}$ and therefore does not contribute to the pseudouridine peak. Thus, the mature $23 \mathrm{~S}$ rRNA contains nine pseudouridines. The $23 \mathrm{~S}$ rRNA of precursor particles lacking methylation at $\Psi 1915$ can contain 10 pseudouridine residues.

The chromatographic analysis does not answer the question of which $\Psi$ residues are underrepresented in the subribosomal particles. To answer this question, chemical modification of 23S rRNA followed by reverse transcriptase-directed primer extension was used. The presence of pseudouridine at a particular position is indicated by the primer extension stop on the CMCT-treated RNA (+ lane) and its absence on the control RNA ( - lane). We used five primers to analyze all nine pseudouridines of $23 \mathrm{~S}$ rRNA of $35 \mathrm{~S}$ and $45 \mathrm{~S}$ particles, free $50 \mathrm{~S}$ subunits, and $70 \mathrm{~S}$ ribosomes for comparison.

All three uridines in helix 69 of E. coli $23 \mathrm{~S}$ rRNA are isomerized to pseudouridines $(\Psi 1911$, $\mathrm{m}^{3} \Psi 1915$, and $\Psi 1917$ ) by RluD (Huang et al. 1998; Raychaudhuri et al. 1998). Methylation of $\Psi 1915$ causes a primer extension stop independent of CMCT treatment (Fig. 5). It must be noted that $\mathrm{m}^{3} \Psi$ can form a Watson-Crick-like base pair in the syn conformation of glycosidic bond allowing a low level of readthrough by reverse transcriptase. Therefore, it was not possible to identify pseudouridylation at position 1915 of $50 \mathrm{~S}$ and $70 \mathrm{~S}$ but the upstream $\Psi 1911$ was still detectable. In the $35 \mathrm{~S}$ particles of both drugs, the $\Psi$-specific signals at 1911 and 1917 are not detectable. In the $45 \mathrm{~S}$ particles all three pseudourindines appear to be pressubunit assembly

Details as in Table 1. ent at low levels. The fraction of $\Psi 1911$ and $\Psi 1917$ is further increased in the free $50 \mathrm{~S}$ particles but is clearly lower compared with the pseudouridylation level of $70 \mathrm{~S}$ ribosomes (Fig. 5). The results indicate that RluD is specific to the late assembly of the large ribosome subunit. This conclusion is supported by the earlier findings that RluD-specific $\Psi$ residues are made on the level of 50S particles in the RNA helicase DeaD deletion strain (Leppik et al. 2007) and that the RluD modifies 50S subunits and 70S ribosomes more specifically and efficiently than protein-free 23S rRNA (Vaidyanathan et al. 2007).

A CMCT-independent reverse transcriptase stop site at position 1915 of $23 \mathrm{~S}$ rRNA indicates the presence of $\mathrm{m}^{3} \Psi$. $23 \mathrm{~S}$ rRNA of $35 \mathrm{~S}$ and 45 particles exhibit a very low CMCTindependent stop signal. In the 50S the stop is strong and in the mature 23S rRNA of 70S ribosomes the stop is very strong (Fig. 5). This shows that the enzyme RlmH responsible for methylation of $\Psi 1915$ at C3 is specific to the very late steps of large ribosome subunit assembly. This conclusion is supported by the fact that $\mathrm{RlmH}$ requires the presence of the $30 \mathrm{~S}$ subunit (Ero et al. 2008).

All other pseudouridines were present in the $35 \mathrm{~S}$ and $45 \mathrm{~S}$ subribosomal particles of both antibiotics. In the free $50 \mathrm{~S}$ subunits the level of pseudouridines was similar to that of $70 \mathrm{~S}$ ribosomes (data not shown). Taking into account the HPLC results described above, this suggests that the $\Psi$ residues outside of helix-loop 69 are made during the early steps of large ribosome subunit assembly. Thus, the corresponding pseudouridine synthases RluA ( $\Psi 746)$, RluB ( $\Psi 2605)$, RluC ( $\Psi 955, \Psi 2504, \Psi 2580)$, RluE ( $\Psi 2457)$, and RluF ( $\Psi 2604)$ are specific to the early assembly particles.

\section{DISCUSSION}

The nucleoside composition of subribosomal particles demonstrates that the modification pattern of rRNA is similar in both erythromycin and chloramphenicol-induced particles of the same size. Modifications are added gradually during

TABLE 3. Nucleoside composition of $23 \mathrm{~S}$ rRNA of different stages of large ribosome

\begin{tabular}{lrcccc}
\hline Nucleoside & Free $50 \mathrm{~S}$ & Ery $45 \mathrm{~S}$ & Cam 45S & Ery 35S & Cam 35S \\
\hline$\psi$ & $89 \pm 3$ & $78 \pm 4$ & $80 \pm 2$ & $69 \pm 6$ & $65 \pm 3$ \\
$\mathrm{~m}^{1} \mathrm{G}(745)$ & $95 \pm 4$ & $89 \pm 4$ & $92 \pm 2$ & $92 \pm 1$ & $92 \pm 9$ \\
$\mathrm{~m}^{5} \mathrm{U}(747,1939)$ & $84 \pm 3$ & $68 \pm 5$ & $72 \pm 2$ & $54 \pm 1$ & $52 \pm 5$ \\
$\mathrm{~m}^{6} \mathrm{~A}(1618,2030)$ & $100 \pm 3$ & $101 \pm 29$ & $92 \pm 1$ & $78 \pm 1$ & $80 \pm 3$ \\
$\mathrm{~m}^{2} \mathrm{G}(1835,2445)$ & $90 \pm 3$ & $82 \pm 3$ & $80 \pm 2$ & $83 \pm 1$ & $87 \pm 10$ \\
$\mathrm{~m}^{5} \mathrm{C}(1962)$ & $66 \pm 3$ & $56 \pm 7$ & $48 \pm 3$ & $41 \pm 2$ & $42 \pm 7$ \\
$\mathrm{~m}^{7} \mathrm{G}(2069)$ & $103 \pm 6$ & $79 \pm 6$ & $80 \pm 4$ & $55 \pm 16$ & $83 \pm 10$ \\
$\mathrm{Gm}(2251)$ & $98 \pm 4$ & $59 \pm 5$ & $38 \pm 1$ & $49 \pm 2$ & $46 \pm 1$ \\
$\mathrm{Cm}(2498)$ & $89 \pm 4$ & $77 \pm 1$ & $89 \pm 4$ & $42 \pm 9$ & $52 \pm 1$ \\
$\mathrm{~m}^{2} \mathrm{~A}(2503)$ & $100 \pm 2$ & $92 \pm 9$ & $92 \pm 1$ & $85 \pm 2$ & $80 \pm 0$ \\
$\mathrm{Um}(2552)$ & $63 \pm 11$ & $32 \pm 11$ & $35 \pm 6$ & 0 & 0 \\
\hline
\end{tabular}




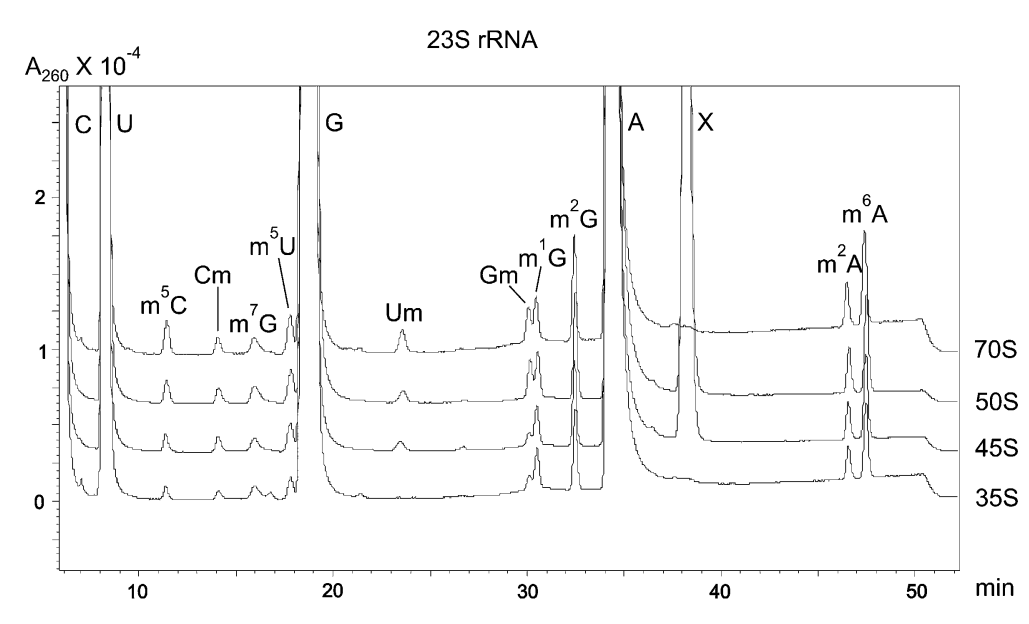

FIGURE 4. HPLC analysis of $23 \mathrm{~S}$ rRNA. $23 \mathrm{~S}$ rRNA was isolated from mature $70 \mathrm{~S}$ ribosomes, free $50 \mathrm{~S}$ subunits, Cam 45S, and Cam $35 \mathrm{~S}$ particles. Peaks corresponding to four standard nucleosides (C, $U, G$, and $A$ ) and $m^{5} \mathrm{C}, \mathrm{Cm}, \mathrm{m}^{7} \mathrm{G}, \mathrm{m}^{5} \mathrm{U}, \mathrm{Um}, \mathrm{Gm}, \mathrm{m}^{1} \mathrm{G}, \mathrm{m}^{2} \mathrm{G}, \mathrm{m}^{2} \mathrm{~A}$, and $\mathrm{m}^{6} \mathrm{~A}$ are indicated. Peak corresponding to the $\mathrm{m}^{5} \mathrm{C}$ contains also $\mathrm{m}^{3} \Psi$. $\mathrm{X}$ corresponds to an unknown compound.

association of r-proteins with the rRNA and thereby with the growing S-value indicating that the synthesis of rRNA modified nucleosides depends on the progression of ribosome assembly.

Two modified nucleosides are added to the rRNA at equal levels during all steps of ribosome assembly. The modifications $\mathrm{m}^{4} \mathrm{Cm} 1402$ of $16 \mathrm{~S}$ rRNA are synthesized in an apparently stochastic way throughout the ribosome subunit assembly. Kimura and Suzuki (2010) reported recently that in the cell-free assay $30 \mathrm{~S}$ subunit, and not free $16 \mathrm{~S}$ rRNA, is the substrate for $\mathrm{RsmH}$ and $\mathrm{RsmI}$ in $\mathrm{m}^{4} \mathrm{Cm} 1402$ formation. Other rRNA modifications can be divided into three groups: early, intermediate, and late assembly specific modifications.

In the $16 \mathrm{~S}$ rRNA of $25 \mathrm{~S}$ particles the fraction of $\mathrm{m}^{5} \mathrm{C}$ is $\sim 50 \%$ and in the free $30 \mathrm{~S}$ subunits $\sim 60 \%$ (Fig. 3; Table 1). Thus, about half of $\mathrm{m}^{5} \mathrm{C}$ is added to the $16 \mathrm{~S}$ rRNA during the early step and the second half during the late steps of ribosome small subunit assembly. Notably, only a small fraction of $\mathrm{m}^{5} \mathrm{C}$ is added during $25 \mathrm{~S}$ to $30 \mathrm{~S}$ transition of the ribosome small subunit. The fact that the first half of $\mathrm{m}^{5} \mathrm{C}$ is added during the early step and the second half during the late stages of ribosome small subunit assembly suggests that the RsmB (methylates C967) and RsmF (C1407) have different specificity with respect to ribosome assembly. Cell-free studies have revealed that RsmB can methylate C967 only on the protein-free 16S rRNA and is blocked when the ribosomal proteins S7 and S19 are added (Weitzmann et al. 1991). Methylation of C1407 is thought to be a late event during ribosome assembly as the in vitro substrate of $\mathrm{RsmF}$ is a $30 \mathrm{~S}$ subunit rather than naked $16 \mathrm{~S}$ rRNA (Andersen and Douthwaite 2006). Based on the results of the nucleoside composition of assembly intermediate particles and enzyme specificity in vitro, we propose that $\mathrm{m}^{5} \mathrm{C} 967$ is made during the early step and $\mathrm{m}^{5} \mathrm{C} 1407$ during the late events of small subunit assembly.
A significant fraction of $\Psi 516$ is added during early and intermediate steps (transition 25S to 30S) of small subunit assembly. This observation agrees with the known specificity of RsuA (Wrzesinski et al. 1995). Formation of $\mathrm{m}^{7} \mathrm{G} 527$ of $16 \mathrm{~S}$ rRNA is clearly an intermediate assembly event. Other modified nucleosides of $16 \mathrm{~S}$ rRNA $\left(\mathrm{m}^{2} \mathrm{G}\right.$ at 966,1207 , $1516 ; \mathrm{m}^{5} \mathrm{C} 1407 ; \mathrm{m}^{3} \mathrm{U} 1498 ; \mathrm{m}^{6}{ }_{2} \mathrm{~A}$ at 1518 and 1519) are synthesized at the level of the 30 S subunit during the late steps of ribosome assembly. Thus, seven out of 11 modified nucleosides of $16 \mathrm{~S}$ rRNA are late assembly specific. This tendency was noted earlier by Kaczanowska and Rydén-Aulin (2007), based on a comprehensive review by Ofengand and Del Campo (2004). The results on the $16 \mathrm{~S}$ rRNA-specific modification enzymes determined in this study are summarized in Figure 6A.

The modified nucleoside composition of $23 \mathrm{~S}$ rRNA in the early assembly particles (35S) reveals the early assembly specific modifications in the large ribosome subunit. All pseudouridines, except the RluD-specific ones in helix-loop 69 of $23 \mathrm{~S}$ rRNA, m ${ }^{1} \mathrm{G} 745, \mathrm{~m}^{6} \mathrm{~A} 1618, \mathrm{~m}^{6} \mathrm{~A} 2030, \mathrm{~m}^{7} \mathrm{G} 2069$, $\mathrm{m}^{2} \mathrm{G} 1835, \mathrm{~m}^{2} \mathrm{G} 2495$, and $\mathrm{m}^{2} \mathrm{~A} 2503$ are clearly early assembly specific (Fig. 6B).

Single $\mathrm{m}^{5} \mathrm{C}$ residue at position 1962 of E. coli $23 \mathrm{~S} \mathrm{rRNA}$ is the product of RlmI (YccW) (Purta et al. 2008). The peak at 11.4 min of the HPLC derived from $35 \mathrm{~S}, 45 \mathrm{~S}$ particles, and from free $50 \mathrm{~S}$ subunits constitutes $40 \%, 50 \%$, and $70 \%$, respectively (Fig. 3; Table 2). This peak contains two nucleosides $\mathrm{m}^{5} \mathrm{C}$ and $\mathrm{m}^{3} \Psi$ (Gehrke and Kuo 1989). The absorbance at $260 \mathrm{~nm}$ of $\mathrm{m}^{5} \mathrm{C}$ and $\mathrm{m}^{3} \Psi$ is roughly equal. We anticipate that in $70 \mathrm{~S}$ both nucleosides contribute to the peak

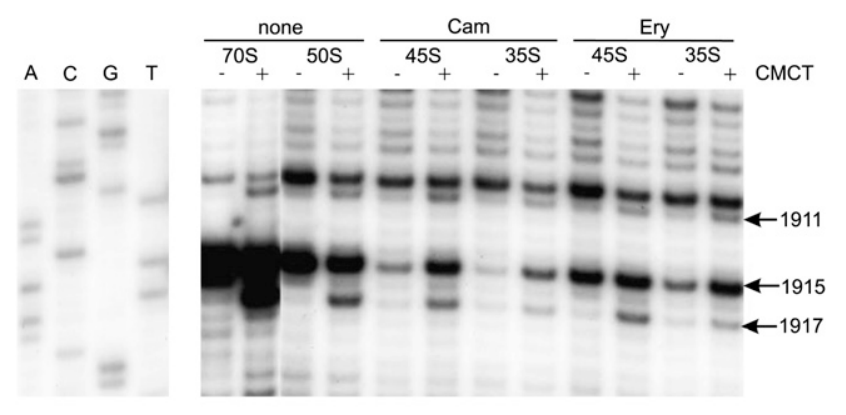

FIGURE 5. Primer extension analysis of the pseudouridines in helixloop 69 of $23 \mathrm{~S}$ rRNA. 23S rRNA was isolated from mature $70 \mathrm{~S}$ ribosomes, free 50S subunits, and Cam 45S, Ery 45S, Cam 35S, and Ery $35 \mathrm{~S}$ particles and analyzed for pseudouridines by CMCT/alkali and reverse transcriptase directed primer extension. +, CMCT/alkali treatment; -, untreated RNA. Sequence of the $23 \mathrm{~S}$ rRNA around helix-loop 69 is shown in sequencing lanes $(\mathrm{A}, \mathrm{C}, \mathrm{G}, \mathrm{T})$. Note that the CMCT induced stop site is one nucleotide below the actual site. 
A

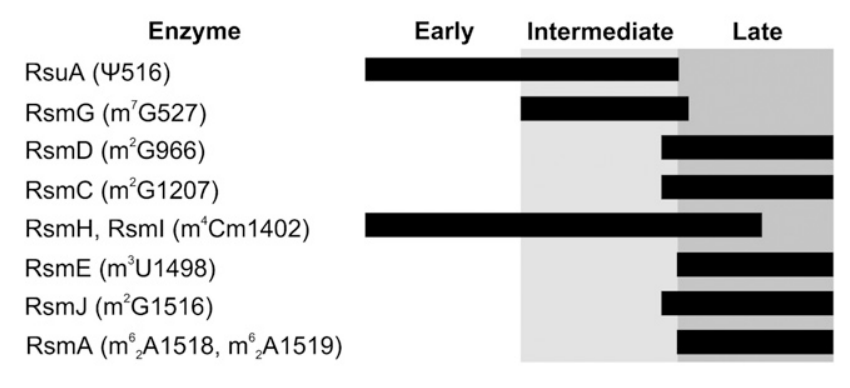

B

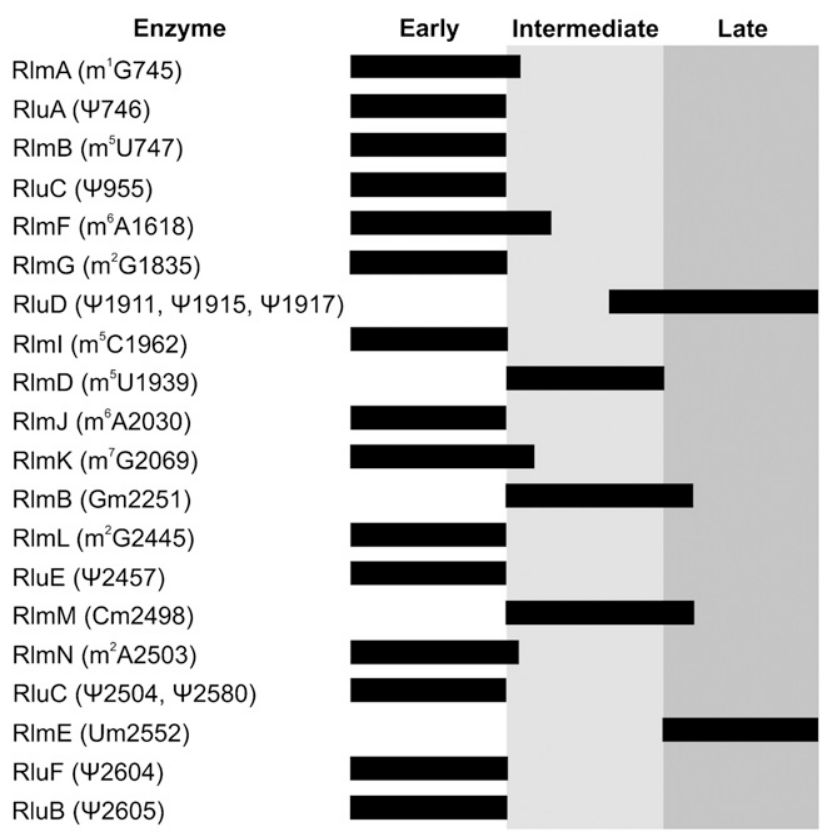

FIGURE 6. Summary of the specificity of the rRNA modification enzymes with respect to ribosome subunit assembly. Ribosome assembly is divided into three stages (early, intermediate, and late), which are shown by white and gray zones. Activity of rRNA modification enzymes is shown by black bars. (A) Modification of $16 \mathrm{~S}$ rRNA. (B) Modification of $23 \mathrm{~S}$ rRNA.

at $11.4 \mathrm{~min}$ by $50 \%$. Thus, the distribution of the two nucleosides is not immediately clear from the data. The intensity of the reverse transcriptase stop site at position 1915 shows that $23 \mathrm{~S}$ rRNA of 35 S particles does not contain $\mathrm{m}^{3} \Psi$, and $45 \mathrm{~S}$ particles contain only a small fraction of $\mathrm{m}^{3} \Psi$ (Fig. $5)$. The formation of $\mathrm{m}^{3} \Psi$ was shown to occur on the level of the $70 \mathrm{~S}$ ribosomes (Ero et al. 2008). Therefore, the 11.4-min peaks of the $35 \mathrm{~S}$ and $45 \mathrm{~S}$ particles probably contain mostly $\mathrm{m}^{5} \mathrm{C}$. Moreover, $\sim 80 \%$ of the free $50 \mathrm{~S}$ subunits are incompletely assembled precursors of the large ribosome subunit (Peil et al. 2008; Al Refaii and Alix 2009). Thus, the 11.4-min peak of the free $50 \mathrm{~S}$ can contain only $20 \%$ of mature 23S rRNA and the corresponding amount of $\mathrm{m}^{3} \Psi$. Therefore, $\mathrm{m}^{5} \mathrm{C}$ is present in the free $50 \mathrm{~S}$ particles by $\sim 100 \%$. These results show that $\mathrm{C} 1962$ is methylated at C5 during early assembly. This is consistent with the in vitro results showing that methyltransferase RlmI is active on the naked 23S rRNA molecules. No methylation was detected on the 50S subunits or tight-couple 70S ribosomes (Purta et al. 2008).

E. coli $23 \mathrm{~S}$ rRNA contains two $\mathrm{m}^{5} \mathrm{U}$ residues $\left(\mathrm{m}^{5} \mathrm{U} 747\right.$, $\mathrm{m}^{5} \mathrm{U} 19389$ ). $\mathrm{m}^{5} \mathrm{U}$ is found in the $35 \mathrm{~S}$ particles in $\sim 50 \%$ (Table 3). The amount of $\mathrm{m}^{5} \mathrm{U}$ methylation increases from $35 \mathrm{~S}$ to $45 \mathrm{~S}$ particles by $20 \%$ and reaches about $85 \%$ in the free $50 \mathrm{~S}$ subunits (Fig. 3; Table 1). This suggests that one $\mathrm{m}^{5} \mathrm{U}$ is made during the early step and the second $m^{5} U$ is made during the intermediate steps of $50 \mathrm{~S}$ maturation. The nucleotide $\mathrm{m}^{5} \mathrm{U} 747$ is located close to the peptide exit tunnel deep inside the mature 50S subunit (Schuwirth et al. 2005). Other modified nucleosides in the 750 loop of $23 \mathrm{~S}$ rRNA ( $\left.\mathrm{m}^{1} \mathrm{G} 745, \Psi 746\right)$ are made during early assembly (Fig. 6B). Therefore it is reasonable to assume that $\mathrm{m}^{5} \mathrm{U} 747$ is an early assembly specific modification, too.

Taken together, early assembly specific modifications are $\mathrm{m}^{1} \mathrm{G} 745, \Psi 746, \mathrm{~m}^{5} \mathrm{U} 747, \Psi 955, \mathrm{~m}^{6} \mathrm{~A} 1618, \mathrm{~m}^{6} \mathrm{~A} 2030$, $\mathrm{m}^{7} \mathrm{G} 2069, \mathrm{~m}^{2} \mathrm{G} 1835, \mathrm{~m}^{5} \mathrm{C} 1962, \Psi 2457, \mathrm{~m}^{2} \mathrm{G} 2495, \mathrm{~m}^{2} \mathrm{~A} 2503$, $\Psi 2504, \Psi 2580, \Psi 2604$, and $\Psi 2605$ (Fig. 6B). Thus, 17 out of 25 modified nucleosides of $23 \mathrm{~S}$ rRNA are made during the early steps of ribosome assembly. The limited time window for synthesis of nucleoside modifications during the large ribosome subunit assembly requires efficient coordination of ribosome assembly events.

As discussed above, the nucleotide $\mathrm{m}^{5} \mathrm{U} 747$ is synthesized during the early stages of 50S subunit assembly. Therefore, the second $\mathrm{m}^{5} \mathrm{U}$ at position 1939 is made during the intermediate assembly events. We conclude that nucleotides $\mathrm{m}^{5} \mathrm{U} 1939, \mathrm{Gm} 2251$, and $\mathrm{Cm} 2498$ are synthesized during the intermediate steps of the large ribosome subunit assembly. It is evident that the corresponding regions of $23 \mathrm{~S} \mathrm{rRNA}$ are accessible for the modification enzymes RlmD, RlmB, and RlmM not only on the protein-free precursor-23S rRNA but also during the intermediate steps of large ribosome subunit assembly. Substrate specificity is known only for the RlmM, which is able to catalyze methylation of C2498 in the proteinfree $23 \mathrm{~S}$ rRNA but not in the tight-coupled $70 \mathrm{~S}$ ribosomes or 50S subunits (Purta et al. 2009).

$23 \mathrm{~S}$ rRNA of free $50 \mathrm{~S}$ subunits contains $\sim 60 \%$ of Um (Table 3) and low levels of U1911 and U1917 (Fig. 5). Thus, the late assembly events of the large ribosome subunit involve formation of Um2552, and isomerization of the uridines in h69.

It is important to stress that the assembly dependence of rRNA modification in vivo is in very good agreement with the published specificities of modification enzymes determined in vitro, as is evident by comparing Table 1 and Figure 6.

Coordination of the rRNA modification and the association of ribosomal protein with the subunit is important for several reasons. First, rRNA folding is a step-wise process where transient structures play an important role (Besancon and Wagner 1999; Liiv and Remme 2004; Adilakshmi et al. 
2008). Therefore, the structures that are recognized by modification enzymes are formed during the progression of ehe ribosome subunit assembly. The second aspect is the role of ribosomal proteins in directing rRNA folding upon binding to the rRNA (Holmes and Culver 2004; Talkington et al. 2005). In this way, r-proteins could help to create the recognition sites for rRNA modification enzymes. On the other hand, r-proteins can inhibit rRNA modification by shielding the modification site. The dual role of $r$-proteins in rRNA modification is illustrated by proteins S7 and S19, which are necessary for the $\mathrm{m}^{2} \mathrm{G} 966$ formation by RsmD but block the synthesis of $\mathrm{m}^{5} \mathrm{C} 967$ by RsmB (Weitzmann et al. 1991). The modification sites that are buried deep inside the subunit must be modified during early assembly. Finally, it is noteworthy that a specific set of r-proteins are exchangeable in vivo (Pulk et al. 2010). When the ribosome bound r-proteins can be exchanged with the free r-proteins, they could be displaced by the rRNA modifications as well. In this way, the rRNA modification sites that are already masked by r-proteins, can become accessible to the modification enzymes during the late stages of ribosome assembly.

\section{MATERIALS AND METHODS}

\section{Preparation of rRNA}

Escherichia coli strain MG1655 (Blattner et al. 1997) was used in all experiments. Cells were grown at $25^{\circ} \mathrm{C}$ in $200 \mathrm{~mL} 2 \times$ YT medium (Sambrook and Russell 2001) until the $\mathrm{A}_{600}$ reached 0.2. At this point, either erythromycin (final concentration of $100 \mu \mathrm{g} / \mathrm{mL}$ ) or chloramphenicol (final concentration of $7 \mu \mathrm{g} / \mathrm{mL}$ ) was added, followed by incubation for $2 \mathrm{~h}$ at $25^{\circ} \mathrm{C}$. The control culture was grown without antibiotics. Bacterial cells were collected by centrifugation in a Sorvall GS-3 rotor at $4000 \mathrm{rpm}$ at $4^{\circ} \mathrm{C}$ for 10 min and were resuspended in $1 \mathrm{~mL}$ lysis buffer $(60 \mathrm{mM} \mathrm{KCl}, 60$ $\mathrm{mM} \mathrm{NH} \mathrm{N}_{4} \mathrm{Cl}, 50 \mathrm{mM}$ Tris- $\mathrm{HCl}[\mathrm{pH} 8], 6 \mathrm{mM} \mathrm{MgCl}_{2}, 6 \mathrm{mM}$ $\beta$-mercaptoethanol, 16\% sucrose); lysozyme and DNase I (Amresco, GE Healthcare) were added to final concentrations of $1 \mathrm{mg} / \mathrm{mL}$ and $20 \mathrm{U} / \mathrm{mL}$, respectively. Cells were frozen for $15 \mathrm{~min}$ at $-70^{\circ} \mathrm{C}$ and subsequently thawed in ice-cold water for $30 \mathrm{~min}$. The freeze-thaw cycle was repeated twice, followed by centrifugation at $13,000 \mathrm{~g}$ and $4^{\circ} \mathrm{C}$ for $20 \mathrm{~min}$. Clear lysate was diluted twofold with buffer A $\left(60 \mathrm{mM} \mathrm{KCl}, 60 \mathrm{mM} \mathrm{NH}_{4} \mathrm{Cl}, 10 \mathrm{mM}\right.$ Tris$\mathrm{HCl}[\mathrm{pH} \mathrm{8}], 12 \mathrm{mM} \mathrm{MgCl}, 6 \mathrm{mM} \beta$-mercaptoethanol). Diluted lysates $(2 \mathrm{~mL}$ ) were loaded onto $30 \mathrm{~mL}, 10 \%-25 \%$ (w/w) sucrose gradient in buffer A. Ribosomal particles were separated by centrifugation at $23,000 \mathrm{rpm}$ in an SW28 rotor (Beckman) at $4^{\circ} \mathrm{C}$ for $13.5 \mathrm{~h}$. Ribosome profiles were detected by continuous monitoring of absorbance at $254 \mathrm{~nm}$. $70 \mathrm{~S}$ ribosomal particles were precipitated with 2.5 volumes of ice-cold ethanol and collected by centrifugation at $5000 \mathrm{rpm}$ for $30 \mathrm{~min}$ in an HS4 rotor (Sorvall). $50 \mathrm{~S}$ and $30 \mathrm{~S}$ subunit fractions from untreated cells, and 45S, 35S, and $25 \mathrm{~S}$ particle fractions from antibiotic-treated cells were diluted twofold with buffer A and concentrated by ultrafiltration using Amicon Ultracel-100k filters. Ribosomal particles were loaded onto sucrose gradients and separated as described above. Ribosomal particles were precipitated by addition of ethanol
(2 volumes). rRNA was deproteinized by extraction with phenol and chloroform followed by ethanol precipitation. RNA was dissolved in water and stored at $-80^{\circ} \mathrm{C}$. $16 \mathrm{~S}$ and $23 \mathrm{~S}$ rRNA from $70 \mathrm{~S}$ ribosomes and $35 \mathrm{~S}$ particles were separated by centrifugation in $5 \%-20 \%(\mathrm{w} / \mathrm{w})$ sucrose gradient (buffer $20 \mathrm{mM} \mathrm{Na}$-acetate, $100 \mathrm{mM} \mathrm{NaCl}, 1 \mathrm{mM}$ EDTA) at $25700 \mathrm{rpm}$ in an SW28 rotor (Beckman) at $4^{\circ} \mathrm{C}$ for $16 \mathrm{~h}$. Purified $16 \mathrm{~S}$ and $23 \mathrm{~S}$ rRNA were precipitated with ethanol.

\section{High-performance liquid chromatography}

For HPLC analysis, 2-4 $\mathrm{A}_{260}$ Units rRNA (70-100 pmol) was digested with nuclease P1 (MP Biochemicals) and bacterial alkaline phosphatase (Fermentas Life Sciences) according to the method of Gehrke and Kuo (1989). Nucleoside composition was determined by RP-HPLC on a Supelcosil LC-18-S HPLC column $(25 \mathrm{~cm} \times 4.6 \mathrm{~mm}, 5 \mu \mathrm{m})$ equipped with a precolumn $(4.6 \mathrm{~mm} \times$ $20 \mathrm{~mm})$ at $30^{\circ} \mathrm{C}$ on a SHIMADZU Prominence HPLC system. The following buffers were used: buffer A $\left(10 \mathrm{mM} \mathrm{NH}_{4} \mathrm{H}_{2} \mathrm{PO}_{4}, 2.5 \%\right.$ methanol at $\mathrm{pH} 5.3)$; buffer $\mathrm{B}\left(10 \mathrm{mM} \mathrm{NH}_{4} \mathrm{H}_{2} \mathrm{PO}_{4}, 20 \%\right.$ methanol at $\mathrm{pH} 5.1)$; and buffer $\mathrm{C}\left(10 \mathrm{mM} \mathrm{NH}_{4} \mathrm{H}_{2} \mathrm{PO}_{4}, 35 \%\right.$ acetonitrile at $\mathrm{pH}$ 4.9). RP-HPLC analysis was performed using the gradient conditions of Gehrke and Kuo (1989): flow rate $1.0 \mathrm{~mL} / \mathrm{min}$ held at $0 \%$ buffer B $12 \mathrm{~min}$, to $10 \%$ buffer B over $8 \mathrm{~min}$, to $25 \%$ buffer $\mathrm{B}$ over $5 \mathrm{~min}$, to $60 \%$ buffer B over $8 \mathrm{~min}$, to $64 \%$ buffer B over $4 \mathrm{~min}$, to $100 \%$ buffer B over $9 \mathrm{~min}, 0 \%-100 \%$ buffer $\mathrm{C}$ over $35 \mathrm{~min}$, held at $100 \%$ buffer $\mathrm{C}$ for $10 \mathrm{~min}$, and equilibration with $0 \%$ buffer B for $30 \mathrm{~min}$. Nucleoside absorbance profiles were recorded at 260 and $280 \mathrm{~nm}$, and peak areas were integrated. Quantitative calculations were according to the following formula: $\mathrm{X} \%=\left(\mathrm{X}_{\mathrm{P}} / \mathrm{N}_{\mathrm{P}}\right) /\left[\right.$ Average $\left.\left(\mathrm{X}_{70 \mathrm{~S}} / \mathrm{N}_{70 \mathrm{~S}}\right)\right] 100$, where $\mathrm{X} \%$ is percentage of modified nucleoside in the subribosomal particle; $\mathrm{X}_{\mathrm{P}}$ ismodified nucleoside area of the subribosomal particle; $\mathrm{X}_{70 \mathrm{~S}}$ is modified nucleoside area of the $70 \mathrm{~S}$ ribosomes; $\mathrm{N}_{\mathrm{P}}$ is area of corresponding unmodified nucleoside of the subribosomal particles; and $\mathrm{N}_{70 \mathrm{~S}}$ is area of corresponding unmodified nucleoside of the $70 \mathrm{~S}$ ribosomes.

\section{Determination of pseudouridines}

Pseudouridines were determined according to the method of Ofengand et al. (2001). Fifteen micrograms rRNA was dissolved in $20 \mu \mathrm{L}$ water, $80 \mu \mathrm{L}$ of BEU buffer (7 M urea, $4 \mathrm{mM}$ EDTA, 50 $\mathrm{mM}$ Bicine/NaOH $[\mathrm{pH} 8.5])$, and $20 \mu \mathrm{L}$ of $\mathrm{CMCT} / \mathrm{BEU}$ buffer (1 m CMCT in BEU buffer) (CMCT; Sigma-Aldrich Chemie $\mathrm{GmbH}$ ) were added. One hundred microliters of BEU buffer was added to $15 \mu \mathrm{g}$ of rRNA in $20 \mu \mathrm{L}$ of water serving as the negative control. Both samples were incubated at $37^{\circ} \mathrm{C}$ for $20 \mathrm{~min}$ for CMCT modification of $\mathrm{U}, \mathrm{G}$, and $\Psi$ residues. Reaction was stopped by addition of $38 \mu \mathrm{L} 4 \mathrm{M} \mathrm{NaOAc}$ and $600 \mu \mathrm{L}$ of cold $96 \%$ ethanol. Samples were kept at $-20^{\circ} \mathrm{C}$ for $10 \mathrm{~min}$, and the RNA precipitate was collected by centrifugation at $6000 \mathrm{~g}$ and $4^{\circ} \mathrm{C}$. The supernatant was carefully removed and RNA was washed twice with $600 \mu \mathrm{L}$ of $70 \%$ ethanol. The precipitate was dried at $37^{\circ} \mathrm{C}$ for $10 \mathrm{~min}$. rRNA was dissolved in $50 \mu \mathrm{L}$ of NPK buffer $\left(20 \mathrm{mM} \mathrm{NaHCO}_{3}, 30 \mathrm{mM}\right.$ $\mathrm{Na}_{2} \mathrm{CO}_{3}, 2 \mathrm{mM}$ EDTA), and the samples were incubated at $37^{\circ} \mathrm{C}$ for $4 \mathrm{~h}$ to allow removal of CMCT from $\mathrm{U}$ and $\mathrm{G}$ residues. After incubation, rRNA was precipitated and washed as described above. The precipitate was dissolved in $20 \mu \mathrm{L}$ of water and stored at $-20^{\circ} \mathrm{C}$. Pseudouridine sequencing of rRNA was carried out by 
primer extension using primers U1 (CAGCCTGGCCATCATTA CGCC), C7 (ACACCAGTGATGCGTCCAC), C17 (CCACTTTAA ATGGCGAAC), C33 (GTTTGATTGGCCTTTCACCC), and T3 (GCTTTCTTTAAATGATGGCTGCTT), and AMV reverse transcriptase (Seikagaku Corp.) in the presence of $\left[\alpha-{ }^{32} \mathrm{P}\right] \mathrm{dCTP}$ (Amersham Biosciences). The resulting DNA fragments were resolved in $7 \%$ polyacrylamide-urea gel. Radioactivity was visualized by a Typhoon PhosphorImager (GE Healthcare).

\section{ACKNOWLEDGMENTS}

We thank Aivar Liiv, Lauri Peil, Margus Leppik, Tanel Tenson, Kai Virumäe, and Rya Ero (all from the University of Tartu) for help and advice. This work was supported by Estonian Science Foundation Grant No. 7509.

Received March 4, 2010; accepted July 15, 2010.

\section{REFERENCES}

Adesnik M, Levinthal C. 1969. Synthesis and maturation of ribosomal RNA in Escherichia coli. J Mol Biol 46: 281-303.

Adilakshmi T, Bellur DL, Woodson SA. 2008. Concurrent nucleation of $16 \mathrm{~S}$ folding and induced fit in $30 \mathrm{~S}$ ribosome assembly. Nature 455: $1268-1272$.

Al Refaii A, Alix J. 2009. Ribosome biogenesis is temperaturedependent and delayed in Escherichia coli lacking the chaperones DnaK or DnaJ. Mol Microbiol 71: 748-762.

Andersen N, Douthwaite S. 2006. YebU is a m5C methyltransferase specific for 16 S rRNA nucleotide 1407. J Mol Biol 359: 777-786.

Basturea G, Deutscher M. 2007. Substrate specificity and properties of the Escherichia coli 16S rRNA methyltransferase, RsmE. RNA 13: 1969-1976.

Besancon A, Wagner R. 1999. Characterization of transient RNARNA interactions important for the facilitated structure formation of bacterial ribosomal 16S RNA. Nucleic Acids Res 27: 4353-4362.

Blattner FR, Plunkett G III, Bloch CA, Perna NT, Burland V, Riley M, Collado-Vides J, Glasner JD, Rode CK, Mayhew GF, et al. 1997. The complete genome sequence of Escherichia coli K-12. Science 277: 1453-1462.

Bügl H, Fauman E, Staker B, Zheng F, Kushner S, Saper M, Bardwell J, Jakob U. 2000. RNA methylation under heat shock control. Mol Cell 6: 349-360.

Caldas T, Binet E, Bouloc P, Costa A, Desgres J, Richarme G. 2000. The FtsJ/RrmJ heat shock protein of Escherichia coli is a $23 \mathrm{~S}$ ribosomal RNA methyltransferase. J Biol Chem 275: 16414-16419.

Champney W. 2006. The other target for ribosomal antibiotics: Inhibition of bacterial ribosomal subunit formation. Infect Disord Drug Targets 6: $377-390$.

Dagley S, Sykes J. 1959. Effect of drugs upon components of bacterial cytoplasm. Nature 183: 1608-1609.

Dodd J, Kolb J, Nomura M. 1991. Lack of complete cooperativity of ribosome assembly in vitro and its possible relevance to in vivo ribosome assembly and the regulation of ribosomal gene expression. Biochimie 73: 757-767.

Ero R, Peil L, Liiv A, Remme J. 2008. Identification of pseudouridine methyltransferase in Escherichia coli. RNA 14: 2223-2233.

Gehrke C, Kuo K. 1989. Ribonucleoside analysis by reversed-phase highperformance liquid chromatography. J Chromatogr 471: 3-36.

Hansen L, Kirpekar F, Douthwaite S. 2001. Recognition of nucleotide G745 in $23 \mathrm{~S}$ ribosomal RNA by the rrmA methyltransferase. J Mol Biol 310: 1001-1010.

Holmes KL, Culver GM. 2004. Mapping structural differences between 30 S ribosomal subunit assembly intermediates. Nat Struct Mol Biol 11: 179-186.
Huang L, Ku J, Pookanjanatavip M, Gu X, Wang D, Greene P, Santi D. 1998. Identification of two Escherichia coli pseudouridine synthases that show multisite specificity for 23S RNA. Biochemistry 37: 15951-15957.

Kaczanowska M, Rydén-Aulin M. 2007. Ribosome biogenesis and the translation process in Escherichia coli. Microbiol Mol Biol Rev 71: 477-494.

Kimura S, Suzuki T. 2010. Fine-tuning of the ribosomal decoding center by conserved methyl-modifications in the Escherichia coli 16S rRNA. Nucleic Acids Res 38: 1341-1352.

Kowalak JA, Bruenger E, Hashizume T, Peltier JM, Ofengand J, McCloskey JA. 1996. Structural characterization of $\mathrm{U}^{\star}-1915$ in domain IV from Escherichia coli $23 \mathrm{~S}$ ribosomal RNA as 3-methylpseudouridine. Nucleic Acids Res 24: 688-693.

Kurland C, Nomura M, Watson J. 1962. The physical properties of the chloromycetin particles. J Mol Biol 4: 388-394.

Leppik M, Peil L, Kipper K, Liiv A, Remme J. 2007. Substrate specificity of the pseudouridine synthase RluD in Escherichia coli. FEBS J 274: 5759-5766.

Lesnyak D, Sergiev P, Bogdanov A, Dontsova O. 2006. Identification of Escherichia coli $\mathrm{m}^{2} \mathrm{G}$ methyltransferases: I. the ycbY gene encodes a methyltransferase specific for G2445 of the $23 \mathrm{~S}$ rRNA. J Mol Biol 364: 20-25.

Liiv A, Remme J. 2004. Importance of transient structures during post-transcriptional refolding of the pre-23S rRNA and ribosomal large subunit assembly. J Mol Biol 342: 725-741.

Lindahl L. 1975. Intermediates and time kinetics of the in vivo assembly of Escherichia coli ribosomes. J Mol Biol 92: 15-37.

Nierhaus KH. 1991. The assembly of prokaryotic ribosomes. Biochimie 73: 739-755.

Nomura M, Hosokawa K. 1965. Biosynthesis of ribosomes: Fate of chloramphenicol particles and of pulse-labeled RNA in Escherichia coli. J Mol Biol 12: 242-265.

Ofengand J, Del Campo M, Kaya Y. 2001. Mapping pseudouridines in RNA molecules. Methods 25: 365-373.

Ofengand J, Del Campo M. 2004. Modified nucleosides of Escherichia coli ribosomal RNA. In EcoSal-Escherichia coli and Salmonella: Cellular and molecular biology (ed. G Björk), ASM Press, Washington, DC. http://www.ecosal.org/.

Okamoto S, Tamaru A, Nakajima C, Nishimura K, Tanaka Y, Tokuyama S, Suzuki Y, Ochi K. 2007. Loss of a conserved 7-methylguanosine modification in 16S rRNA confers low-level streptomycin resistance in bacteria. Mol Microbiol 63: 1096-1106.

Peil L, Virumäe K, Remme J. 2008. Ribosome assembly in Escherichia coli strains lacking the RNA helicase DeaD/CsdA or DbpA. FEBS J 275: 3772-3782.

Poldermans B, Roza L, Van Knippenberg PH. 1979. Studies on the function of two adjacent N6,N6-dimehyadenosines near the 3' end of $16 \mathrm{~S}$ ribosomal RNA of Escherichia coli. III Purification and properties of the methylating enzyme and methylase-30 S interaction. J Biol Chem 254: 9094-9100.

Pulk A, Liiv A, Peil A, Maiväli Ü, Nierhaus KH, Remme J. 2010. Ribosome reactivation by replacement of damaged proteins. Mol Microbiol 75: 801-814.

Purta E, O'Connor M, Bujnicki J, Douthwaite S. 2008. YccW is the m5C methyltransferase specific for 23S rRNA nucleotide 1962. J Mol Biol 383: 641-651.

Purta E, O'Connor M, Bujnicki J, Douthwaite S. 2009. YgdE is the 2'-O-ribose methyltransferase RlmM specific for nucleotide C2498 in bacterial 23S rRNA. Mol Microbiol 72: 1147-1158.

Raychaudhuri S, Conrad J, Hall B, Ofengand J. 1998. A pseudouridine synthase required for the formation of two universally conserved pseudouridines in ribosomal RNA is essential for normal growth of Escherichia coli. RNA 4: 1407-1417.

Sambrook J, Russell DW. 2001. Molecular cloning: A laboratory manual, 3rd ed. Cold Spring Harbor Laboratory Press, Cold Spring Harbor, NY.

Schuwirth B, Borovinskaya M, Hau C, Zhang W, Vila-Sanjurjo A, Holton J, Cate J. 2005. Structures of the bacterial ribosome at $3.5 \AA$ resolution. Science 310: 827-834. 
Sergiev P, Lesnyak D, Bogdanov A, Dontsova O. 2006. Identification of Escherichia coli $\mathrm{m} 2 \mathrm{G}$ methyltransferases: II. The ygjO gene encodes a methyltransferase specific for G1835 of the $23 \mathrm{~S}$ rRNA. J Mol Biol 364: 26-31.

Sergiev P, Serebryakova M, Bogdanov A, Dontsova O. 2008. The ybiN gene of Escherichia coli encodes adenine-N6 methyltransferase specific for modification of A1618 of $23 \mathrm{~S}$ ribosomal RNA, a methylated residue located close to the ribosomal exit tunnel. J Mol Biol 375: 291-300.

Siibak T, Peil L, Xiong L, Mankin A, Remme J, Tenson T. 2009. Erythromycin- and chloramphenicol-induced ribosomal assembly defects are secondary effects of protein synthesis inhibition. Antimicrob Agents Chemother 53: 563-571.

Talkington M, Siuzdak G, Williamson J. 2005. An assembly landscape for the 30S ribosomal subunit. Nature 438: 628-632.

Tscherne J, Nurse K, Popienick P, Ofengand J. 1999. Purification, cloning, and characterization of the 16 S RNA m2G1207 methyltransferase from Escherichia coli. J Biol Chem 274: 924-929.
Usary J, Champney W. 2001. Erythromycin inhibition of 50S ribosomal subunit formation in Escherichia coli cells. Mol Microbiol 40: 951-962.

Vaidyanathan P, Deutscher M, Malhotra A. 2007. RluD, a highly conserved pseudouridine synthase, modifies 50S subunits more specifically and efficiently than free $23 S$ rRNA. RNA 13: 18681876.

Weitzmann C, Tumminia S, Boublik M, Ofengand J. 1991. A paradigm for local conformational control of function in the ribosome: Binding of ribosomal protein S19 to Escherichia coli $16 \mathrm{~S}$ rRNA in the presence of S7 is required for methylation of $\mathrm{m} 2 \mathrm{G} 966$ and blocks methylation of m5C967 by their respective methyltransferases. Nucleic Acids Res 19: 7089-7095.

Wrzesinski J, Nurse K, Bakin A, Lane B, Ofengand J. 1995. A dualspecificity pseudouridine synthase: An Escherichia coli synthase purified and cloned on the basis of its specificity for $\psi 746$ in $23 \mathrm{~S}$ RNA is also specific for $\psi 32$ in $\mathrm{tRNA}^{\text {phe }}$. RNA 1: 437-448. 

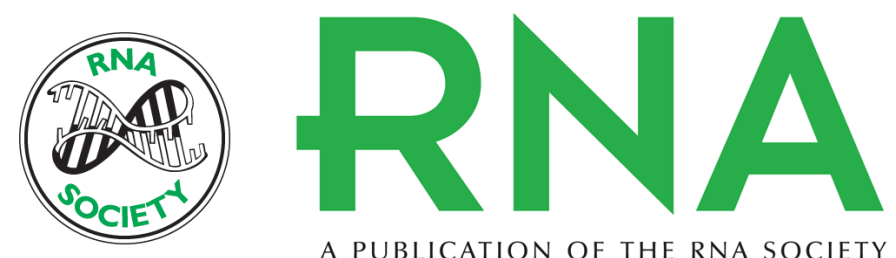

A PUBLICATION OF THE RNA SOCIETY

\section{Subribosomal particle analysis reveals the stages of bacterial ribosome assembly at which rRNA nucleotides are modified}

Triinu Siibak and Jaanus Remme

RNA 2010 16: 2023-2032 originally published online August 18, 2010

Access the most recent version at doi:10.1261/rna.2160010

$\begin{array}{ll}\text { References } & \begin{array}{l}\text { This article cites } 45 \text { articles, } 12 \text { of which can be accessed free at: } \\ \text { http://rnajournal.cshlp.org/content/16/10/2023.full.html\#ref-list-1 }\end{array}\end{array}$

License

Email Alerting Receive free email alerts when new articles cite this article - sign up in the box at the Service top right corner of the article or click here. 